\title{
Helping Language Learners Self-Review Learning Points and Gain Learning Expectation
}

\author{
Dinh T.T. Le \\ Faculty of Foreign Languages, Van Lang University, Vietnam \\ Corresponding author's email:dinh.ltt@vlu.edu.vn
}

\begin{abstract}
Revision after each lesson plays an essential role in enhancing learners' English level, although it is sometimes neglected by students at the tertiary education level. Acknowledging learners' difficulty in reviewing major learning points and their low expectations in classes of writing skills, I decided to apply a technique called "summary cards" to assist students in grasping the main points and logically connect their lessons for the whole picture of the subject. The act also aims at helping review for the final exam when students have to deal with a huge amount of knowledge in order to meet the requirements. Furthermore, a small act of the "summary card" was utilized to assist students in setting their learning goals and gaining their expectations and motivation, which was supposed to help improve both their level of writing and their attitudes towards learning writing skills.
\end{abstract}

After a 10-week course using "summary cards," a class of 36 freshmen at a university showed positive attitudes towards the new measure introduced. It is possible in the future that they apply this new measure in other courses which require them to memorize various learning points.

Keywords: Self-review, Learning expectation, Writing skill

\section{INTRODUCTION}

\subsection{Objectives}

After 7 years working in the Vietnamese tertiary educational environment, I reckon that one of the Vietnamese students' major weaknesses is lack of review, especially freshmen who have just transferred to a new education system at university. The new academic environment at the university has posed a big challenge for first-year students. They are so overwhelmed with the huge amount of knowledge provided in each subject that they have difficulty grasping the main learning points and reviewing for the exams. Furthermore, lack of learning expectation is also a prominent disadvantage, which profoundly affects their language improvement. It is the case that Vietnamese students often go to the class without acknowledging the outcome of the lesson, and they tend to expect nothing from the class which they are about to attend. In other words, first-year students have struggled with setting learning goals for themselves.
To tackle this serious situation, I decided to conduct small-scale research with a 10 -week writing class of freshmen who majored in English. As the main lecturer of the subject, I added an additional step after each lesson in order to require students to summarize what they have learned from the lesson and to figure out what they expect to learn in the next class. The objective of this act is to instruct students how to review the knowledge provided by themselves, together with improving their low learning expectations and adjusting their learning expectations to the right aim.

\subsection{Literature review}

According to Batchelor [1] and Briggs [2], there are diverse reasons why students decide to attend university and to continue or discontinue their studying at the tertiary level, as in [3]. Moving from high school to university is a huge challenge for students, especially those who have to leave their hometown and start a new life far from their family and friends. James [4] also states that "the transition to university is, therefore, a 
particularly significant period for understanding students' expectations and the consequences." Students' feedback on their experience during the first year at university has proved that university culture has caused confusing expectations among freshmen, which was mentioned by Krause, Hartley, James and McInnis [5], and by Wilcox, Winn and Fyvie-Gauld [6]. Therefore, it takes time for students to reorganize their life and adjust their learning strategies to adapt to the new educational environment.

Over the past decades, several applied linguists have focused on learners' strategies and their learning styles as in [7], [8], [9], [10]. Despite diverse learning styles, the review is always an essential part in language learning process, and it becomes even more important at the tertiary level, which students need to do by themselves. According to Reid [11], review means simply "seeing again." Learners need to look back on what they have acquired over a specific period of time in order to reinforce the amount of knowledge before heading to the new one or dealing with various tests and exams.

Bjork and Kroll [12] state that any methods which might improve student performance quickly in the short term would not gain retention of knowledge in the long run. For example, if students perform much better after just one lesson, it is possible that they fail to remember what they have learned in that lesson several months later. Students tend to forget their learning points once they have left the classroom. Therefore, revision after each lesson has been proved to be essential to students' learning process. Besides reviewing after each lesson, it also needs to be conducted over time, i.e., monthly and weekly, in order to strengthen their memory of required knowledge [13].

Additionally, goal setting is also another challenge for freshmen who find it hard to figure it out by themselves. In Classroom Instruction That Works, goal setting is defined as the process of establishing a direction for learning [14]. Moreover, goal setting in language learning is supposed to be one of the strategies that encourage learner autonomy, according to Locke, Shaw, Saari, and Latham [15], Wentzel [16], and Yang [17]. Schunk [18] indicates that goal setting can help students gain motivation and lead them to higher academic achievement, although the goal itself does not benefit students. Nevertheless, goal setting helps students concentrate on the required outcomes and create a clear direction to achieve success [19]. Due to those obvious benefits, in order to improve academic performance, students should be allowed to be in charge of their own goals, as mentioned in [20], [21]. Those who choose their own goals are reported to perform better than those who have others set goals for them, according to Mento, Steel, and Karren [22]. Dotson [19] suggests "students should be taught to record their goals on paper so that they can refer back to it throughout the learning process."

\section{METHODOLOGY AND WORK PLAN}

This is action research with a survey at the final stage to examine students' attitudes towards the new technique applied during their first writing course at university. The level of students is supposed to be pre-intermediate.

A group of 37 freshmen who majored in English attending a 10-week writing course was required to make a "summary card" at the end of each lesson. After the lesson came to an end, the lecturer introduced the next topic, which happened a week later. Then, before leaving the classroom, in 5 minutes, the students were instructed to write their own "summary card", which consisted of 3 main learning points of today's lesson that they could remember at the moment and 3 things they would like to learn in the next lesson based on the topic introduced by the lecturer. Students were not allowed to look through their textbooks and notebooks but tried to recall what they had just learned during the lesson. They were also asked to keep it brief, which meant that the summary card must be short and straightforward, but it must show their understanding after the lesson and their goal, or their expectation, which they set out for themselves. Some of the participants' "summary cards" were presented in Appendix 1.

Before attending the next class, at home, students had to review their previous lesson using the summary card they had made in class. They also needed to pay attention to 3 things they expected to learn so that later they could compare the learning points they would acquire this week with their expectation, or their goal, in the previous week. They then kept their summary cards for later revision and preparation for the final exams. They could also exchange their summary cards with other students for reference. 
After 10 weeks, a survey of 8 questions designed in Likert scale was handed out. Students' attitudes would be investigated at the end of the course to check whether they find the act helpful or not and whether they themselves would apply this act for other subjects in the future.

\section{THE STUDY}

\subsection{Context}

The 10-week writing course aimed at providing students with basic sentence patterns and paragraph organization. Students of B1 level of English were supposed to be suitable for this course. After the course, students were able to recognize sentence patterns and paragraph structures and write a short paragraph (100 - 120 words) about a familiar topic with a clear organization. Every week, students attended a class at school which lasted for 2 hours and 15 minutes. Students were not allowed to be absent for more than $20 \%$ of classes. There was a midterm test in the 6th week and a final exam after the course came to an end.

The research was conducted with 37 freshmen attending this writing course for 10 weeks. The students were at the age of 18 to 19 , B1 level of English, and attended university for the first time. All of them were not familiar with the new educational environment, which was different from their high school. Vietnamese students were accustomed to learning what their teachers told them to learn, and high school teachers tended to point out the most important things included in the upcoming exams for students to focus on. Therefore, when encountering university, students were not used to self-studying and self-reviewing.

Furthermore, the students were not good at taking notes. They were overwhelmed by the amount of knowledge provided in each class and were not able to figure out the main points which they needed to memorize for further study and application. The students also went to class without any expectation about the upcoming lesson, which meant that they heavily relied on what the lecturer provided in class.

I decided to apply for the "summary card" for this writing class to investigate its effects on students' attitudes, thus examining whether the "summary card" could be a promising measure to help students improve their revision and low learning expectation.

\subsection{Data collection}

At the end of the writing course, 37 students were required to finish a survey of 8 questions. All of the questions were designed on Likert scale with 5 levels: strongly disagree, disagree, neutral (undecided), agree and strongly agree. The survey form can be found in Appendix 2 of this research paper.

\subsection{Data analysis}

This is the data collected from all 37 participants.

Table 1. The number of participants replying to each question in the survey.

\begin{tabular}{|l|l|c|c|c|c|c|}
\hline & $\begin{array}{l}\text { Stro } \\
\text { ngly } \\
\text { disa } \\
\text { gree }\end{array}$ & $\begin{array}{l}\text { Disa } \\
\text { gree }\end{array}$ & $\begin{array}{l}\text { Neu } \\
\text { tral }\end{array}$ & $\begin{array}{c}\text { Ag } \\
\text { ree }\end{array}$ & $\begin{array}{l}\text { Stro } \\
\text { ngly } \\
\text { agre } \\
\text { e }\end{array}$ \\
\hline 1 & $\begin{array}{l}\text { Summar } \\
\text { y cards } \\
\text { help } \\
\text { you } \\
\text { acquire } \\
\text { the } \\
\text { main } \\
\text { points } \\
\text { of the } \\
\text { lesson. }\end{array}$ & 0 & 1 & 7 & 12 & 17 \\
\hline 2 & $\begin{array}{l}\text { Summar } \\
\text { y cards } \\
\text { help } \\
\text { you } \\
\text { review } \\
\text { the } \\
\text { lesson } \\
\text { easily. }\end{array}$ & 1 & 1 & 7 & 6 & 22 \\
\hline 3 & $\begin{array}{l}\text { Summar } \\
\text { y cards } \\
\text { help } \\
\text { you } \\
\text { self- } \\
\text { check } \\
\text { your } \\
\text { understa } \\
\text { nding } \\
\text { after } \\
\text { every } \\
\text { lesson. } \\
4\end{array}$ & 0 & 0 & 8 & 10 & 19 \\
\hline $\begin{array}{l}\text { Summar } \\
\text { y cards } \\
\text { make } \\
\text { you } \\
\text { look } \\
\text { forward } \\
\text { to the }\end{array}$ & 1 & 5 & 9 & 12 & 10 \\
\hline
\end{tabular}




\begin{tabular}{|c|l|l|l|l|l|l|}
\hline & $\begin{array}{l}\text { next } \\
\text { lesson. }\end{array}$ & & & & & \\
\hline 5 & $\begin{array}{l}\text { Summar } \\
\text { y cards } \\
\text { help } \\
\text { you set } \\
\text { your } \\
\text { goal for } \\
\text { the next } \\
\text { lesson. }\end{array}$ & 0 & 3 & 11 & 14 & 9 \\
\hline 6 & $\begin{array}{l}\text { Summar } \\
\text { y cards } \\
\text { help } \\
\text { you link } \\
\text { the } \\
\text { lessons } \\
\text { together } \\
\text {. }\end{array}$ & 0 & 2 & 7 & 12 & 16 \\
\hline 7 & $\begin{array}{l}\text { You } \\
\text { like } \\
\text { writing } \\
\text { summar } \\
\text { y cards } \\
\text { after } \\
\text { every } \\
\text { lesson. }\end{array}$ & 2 & 4 & 14 & 6 & 11 \\
\hline 8 & $\begin{array}{l}\text { You are } \\
\text { going to } \\
\text { apply } \\
\text { summar } \\
\text { y cards } \\
\text { for } \\
\text { other } \\
\text { subjects } \\
\text {. }\end{array}$ \\
\hline
\end{tabular}

The table below shows the percentage of the students' answers to each question in the survey.

Table 2. The percentage of the students' answers to each question in the survey.

\begin{tabular}{|l|l|l|l|l|l|l|}
\hline & & $\begin{array}{l}\text { Stro } \\
\text { ngly } \\
\text { disa } \\
\text { gree }\end{array}$ & $\begin{array}{l}\text { Disa } \\
\text { gree }\end{array}$ & $\begin{array}{l}\text { Neu } \\
\text { tral }\end{array}$ & $\begin{array}{l}\text { Ag } \\
\text { ree }\end{array}$ & $\begin{array}{l}\text { Stro } \\
\text { ngly } \\
\text { agre } \\
\text { e }\end{array}$ \\
\hline 1 & $\begin{array}{l}\text { Summa } \\
\text { ry cards } \\
\text { help } \\
\text { you } \\
\text { acquire } \\
\text { the } \\
\text { main } \\
\text { points } \\
\text { of the } \\
\text { lesson. }\end{array}$ & $2.7 \%$ & $\begin{array}{l}18.9 \\
\%\end{array}$ & $\begin{array}{l}32 . \\
4 \%\end{array}$ & $46 \%$ \\
\hline
\end{tabular}

\begin{tabular}{|c|c|c|c|c|c|c|}
\hline 2 & $\begin{array}{l}\text { Summa } \\
\text { ry cards } \\
\text { help } \\
\text { you } \\
\text { review } \\
\text { the } \\
\text { lesson } \\
\text { easily. }\end{array}$ & $\begin{array}{l}2.7 \\
\%\end{array}$ & $2.7 \%$ & $\begin{array}{l}18.9 \\
\%\end{array}$ & $\begin{array}{l}16 . \\
2 \%\end{array}$ & $\begin{array}{l}59.5 \\
\%\end{array}$ \\
\hline 3 & $\begin{array}{l}\text { Summa } \\
\text { ry cards } \\
\text { help } \\
\text { you } \\
\text { self- } \\
\text { check } \\
\text { your } \\
\text { underst } \\
\text { anding } \\
\text { after } \\
\text { every } \\
\text { lesson. }\end{array}$ & $0 \%$ & $0 \%$ & $\begin{array}{l}21.6 \\
\%\end{array}$ & $\begin{array}{l}27 \\
\%\end{array}$ & $\begin{array}{l}51.4 \\
\%\end{array}$ \\
\hline 4 & $\begin{array}{l}\text { Summa } \\
\text { ry cards } \\
\text { make } \\
\text { you } \\
\text { look } \\
\text { forward } \\
\text { to the } \\
\text { next } \\
\text { lesson. }\end{array}$ & $\begin{array}{l}2.7 \\
\%\end{array}$ & $\begin{array}{l}13.5 \\
\%\end{array}$ & $\begin{array}{l}24.4 \\
\%\end{array}$ & $\begin{array}{l}32 . \\
4 \%\end{array}$ & $27 \%$ \\
\hline 5 & $\begin{array}{l}\text { Summa } \\
\text { ry cards } \\
\text { help } \\
\text { you set } \\
\text { your } \\
\text { goal for } \\
\text { the next } \\
\text { lesson. }\end{array}$ & $0 \%$ & $8.1 \%$ & $\begin{array}{l}29.7 \\
\%\end{array}$ & $\begin{array}{l}37 . \\
8 \%\end{array}$ & $\begin{array}{l}24.4 \\
\%\end{array}$ \\
\hline 6 & $\begin{array}{l}\text { Summa } \\
\text { ry cards } \\
\text { help } \\
\text { you link } \\
\text { the } \\
\text { lessons } \\
\text { together }\end{array}$ & $0 \%$ & $5.4 \%$ & $\begin{array}{l}18.9 \\
\%\end{array}$ & $\begin{array}{l}32 . \\
4 \%\end{array}$ & $\begin{array}{l}43.3 \\
\%\end{array}$ \\
\hline 7 & $\begin{array}{l}\text { You } \\
\text { like } \\
\text { writing } \\
\text { summar } \\
\text { y cards } \\
\text { after } \\
\text { every } \\
\text { lesson. }\end{array}$ & $\begin{array}{l}5.4 \\
\%\end{array}$ & $\begin{array}{l}10.8 \\
\%\end{array}$ & $\begin{array}{l}37.8 \\
\%\end{array}$ & $\begin{array}{l}16 . \\
3 \%\end{array}$ & $\begin{array}{l}29.7 \\
\%\end{array}$ \\
\hline 8 & $\begin{array}{l}\text { You are } \\
\text { going to } \\
\text { apply } \\
\text { summar }\end{array}$ & $\begin{array}{l}5.4 \\
\%\end{array}$ & $\begin{array}{l}13.5 \\
\%\end{array}$ & $\begin{array}{l}37.8 \\
\%\end{array}$ & $\begin{array}{l}18 . \\
9 \%\end{array}$ & $\begin{array}{l}24.4 \\
\%\end{array}$ \\
\hline
\end{tabular}




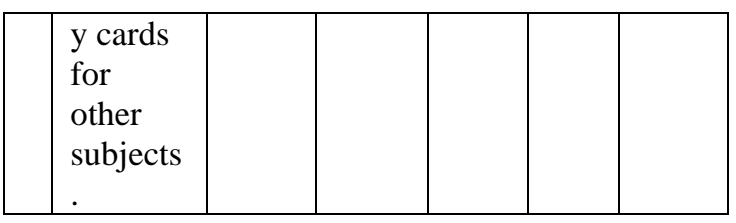

As we could see from table 2, for question 1, nearly $50 \%$ of the participants strongly agree that the summary cards help them get the main points of the lesson, while only $2.7 \%$ of them disagree, and none of them strongly refute the effectiveness of the summary cards in helping them to grasp the lesson's gist.

With question 2 , nearly $60 \%$ of the participants strongly agree that the summary cards assist them in reviewing their lessons at home more easily. However, there are $2.7 \%$ of participants disagree and strongly disagree with this statement.

With question 3, while about $21.6 \%$ of the students have no opinion about whether the summary cards help them self-check their understanding after class or not, the rest of them agree and strongly agree that the summary cards did help them in this field.

With questions 4 and 5, under $30 \%$ of the participants strongly agree with the effectiveness of the summary cards in setting their learning goals and gaining their learning expectations. Similar figures are found in the group of participants who are undecided about this statement. Besides, $2.7 \%$ of the students strongly disagree that the summary cards made them look forward to the next lesson.

With question 6, although $5.4 \%$ of the participants disagree that the summary cards helped them link the lessons together, $32.4 \%$ agree, and $43.3 \%$ strongly agree with this statement.

With questions 7 and 8, under $20 \%$ of the participants show no interest in applying for the summary cards in the future, whereas roughly $45 \%$ of them think they like the summary cards and would probably use them for other subjects. There are $37.8 \%$ of the students hold neutral attitudes towards keeping on using the summary cards by themselves.

\section{THE FINDINGS}

After analyzing the data collected, three main findings are discovered as below.

Firstly, it is proved that the summary cards are useful for students to review their lessons after class due to the fact that over $75 \%$ of them agree and strongly agree with questions 1, 2, 3 and 6 in the survey. Most of the participants admit the summary cards assist them to grasp the gist of the lesson more easily for revision later. Moreover, they also find the summary cards beneficial for them to self-check their understanding after class, then they can adjust their focus or their learning methods for better results in the future. The summary cards also play the role of a connector which helps the participants to link the content of the lessons together so that they can revise their knowledge effectively for the final exam. To be more specific, the summary cards could help them "navigate" their studying during the 10week course.

Secondly, based on the data collected for questions 4 and 5, the summary cards are also effective in gaining students' expectations or helping them to set out their learning goals for themselves. Roughly $60 \%$ of the participants agree and strongly agree that they look forward to the next lesson because of the expectation they have written down in the summary cards. Just about the same number of the students admit that they could set out their learning goal for the next lesson thanks to the summary cards they created in the previous week.

However, the figures for questions 7 and 8 in the survey are not positive. Under 50\% of the participants show their interest in applying for the summary cards by themselves in the future. There are $16.4 \%$ of the students who do not like making summary cards, and $18.9 \%$ of them who refuse to use summary cards for other subjects, while more than a third of the class show their indifference towards to act. It is obvious that the students are not keen on the new method, and unless they are required to take the step of making summary cards after the lesson, they are not likely to do it for themselves.

\section{RECOMMENDATION}

This research has posed some issues which are worth investigating more in the future.

Firstly, this research was only conducted with 37 students, which was a very small population. Thus the results might not be highly persuasive. It is possible that the research should be re-conducted on a larger scale to carefully examine the findings.

Secondly, based on the data collected and analyzed, it is strange that most of the participants 
agree with the effectiveness of the summary cards but refuses to apply the same act in the future for other subjects. Due to lack of time, interviews with the participants were not included in the research for more information about their underlying reasons. Therefore, thorough research should be done to find out the reasons why students are not interested in creating the summary cards for themselves, although they acknowledge the benefits which the summary cards have brought to them.

Thirdly, during this research, the act was performed right in class with a paper card to make summary cards. However, this method could be applied to virtual classes by using applications on mobile phones or other online tools to replace summary cards. Whether the method is effective for virtual class or not is the question for another research in the future. The attitudes of the participants, especially young participants who are familiar with technology, towards making the summary cards might be different if they are required to use technological assistance.

Finally, although more than $60 \%$ of the participants agree that the summary cards help improve their expectations and set their learning goal for every lesson, the number of students who do not show their eagerness to continue applying this effective act is still high. As a result, more measures should be considered to tackle this issue, and more research should be conducted to dig into this field.

\section{CONCLUSION}

In conclusion, the research helps to introduce an effective action to help improve students' revision and gain their learning expectations. Even though the research was conducted on a small scale, the findings are worth considering, as well as recommend other issues for further investigation in the future.

\section{ACKNOWLEDGMENTS}

The authors of this article acknowledged the supports of Van Lang University at 69/68 Dang Thuy Tram St. Ward 13, Binh Thanh Dist., Ho Chi Minh City, Vietnam.

\section{REFERENCES}

[1] D. Batchelor, Becoming what you want to be, London Review of Education, vol. 4, no. 3, 2006, pp. 225-238.
[2] S. Briggs, An exploratory study of the factors influencing undergraduate student choice: the case of higher education in Scotland, in Studies in Higher Education, vol. 31, no. 6, 2006, pp. 705-722.

[3] N. Zepke, Being learner-centered: one way to improve student retention?, in Studies in Higher Education, vol. 31, no. 5, 2006, pp. 587-600.

[4] R. James, Students' changing expectations of higher education and the consequences of mismatches with the reality, in P. Coaldrake \& L. Stedman (Eds), Responding to student expectations, Paris, France: OECD, 2002, pp. 71-83.

[5] K. Krause, R. Hartley, R. James, and G. McInnis, The first-year experience in Australian universities: Findings from a decade of national studies, Melbourne, Australia: Centre for Study of Higher Education, University of Melbourne, 2005 .

[6] P. Wilcox, S. Winn, and M. Fyvie-Gauld, It was nothing to do with the university, it was just the people: The role of social support in the firstyear experience of higher education, in Studies in Higher Education, vol. 30, no. 6, 2005, pp. 707-722.

[7] A. Wenden, and J. Rubin, Learner strategies in language learning, Englewood Cliffs, NJ, USA: Prentice Hall, 1987.

[8] R. L. Oxford, Language learning strategies: what every teacher should know, New York, USA: Newbury House, 1990.

[9] A. U. Chamot, and J. M. O'Malley, Learning strategies in second language acquisition, Cambridge, UK: Cambridge University Press, 1990.

[10] A. D. Cohen, Strategies in learning and using a second language, London, UK: Longman, 1998.

[11] J. M. Reid, Teaching ESL writing, Englewood Cliffs, NJ, USA: Prentice Hall Regents, 1993.

[12] R. A. Bjork, and J. F. Kroll, Desirable difficulties in vocabulary learning, vol. 128, no. 2, 2015, pp. 241-252 [online]. Available: www.jstor.org/stable/10.5406/amerjpsyc.128.2. $\underline{0241}$ 
[13] B. Rosenshine, Principles of instruction: Research-based strategies that all teachers should know, in American Educator, vol. 36, no. 1, 2012 [online]. Available: www.aft.org/sites/default/files/periodicals/Ros enshine.pdf

[14] R. Marzano, D. Pickering, and J. Pollock, Classroom instruction that works, Alexandria, VA, USA: Association for Supervision and Curriculum Development, 2001.

[15] E. A. Locke, K. N. Shaw, L. M. Saari, and G. P. Latham, Goal setting and task performance: 1967-1980, in Psychological Bulletin, vol. 90, 1981, pp. 125-152.

[16] K. R. Wentzel, Social competence at school: Relationship of social responsibility and academic achievement, in Review of Educational Research, vol. 61, 1991, pp. 1-24.

[17] N. Yang, Exploring a new role for teachers: Promoting learner autonomy, in System, vol. 26, 1998, pp. 127-135.

[18] D. Schunk, Goal setting, 2009 [online]. Avaible: http://www.education.com/reference/article/ goalsetting/

[19] R. Dotson, Goal Setting to Increase Student Academic Performance, in The Journal of School Administration Research and Development, vol. 1, no. 1, 2016, pp. 44-46.

[20] R. Azevedo, S. Ragan, J. Cromley, S. Pritchett, et al., Do different goal-setting conditions facilitate students' ability to regulate their learning of complex science topics with RiverWeb?, 2002 [online]. Available: ERIC database (ED482509)

[21] M. Tubbs, Goal setting: A meta-analytic examination of the empirical evidence, in Journal of Applied Psychology, vol. 71, 1986, pp. 474-483.

[22] A. J. Mento, R. P. Steel, and R. J. Karren, A meta-analytic study of the effects of goal setting on task performance: 1966-1984, in Organizational Behavior and Human Decision Processes, vol. 39, 1987, pp. 52-83.

\section{APPENDIX 1. SOME OF STUDENTS" "SUMMARY CARDS"}

$$
\begin{aligned}
& 3 \text { things I remem lered: } \\
& + \text { Learn about wring commas } \\
& +S+\text { make }+O+\text { adj } / V \\
& +S+\text { get }+s . b+t_{0} V \\
& S+\text { have }+ \text { sb }+V \\
& \text { I thing I expected to learn } \\
& + \text { More vocabulary. } \\
& + \text { More. I dioms. } \\
& + \text { More. games. }
\end{aligned}
$$




\section{APPENDIX 2. SURVEY}

Please check $(\checkmark)$ the suitable answer for each question below.

Please answer the question honestly, and do not leave each item unanswered.

1: strongly disagree

2: quite disagree

3: neutral

4: quite agree

5: strongly agree

\begin{tabular}{|c|c|c|c|c|c|c|}
\hline & & 1 & 2 & 3 & 4 & 5 \\
\hline 1 & Summary cards help you acquire the main points of the lesson. & & & & & \\
\hline 2 & Summary cards help you review the lesson easily. & & & & & \\
\hline 3 & $\begin{array}{l}\text { Summary cards help you self-check your understanding after every } \\
\text { lesson. }\end{array}$ & & & & & \\
\hline 4 & Summary cards make you look forward to the next lesson. & & & & & \\
\hline 5 & Summary cards help you set your goal for the next lesson. & & & & & \\
\hline 6 & Summary cards help you link the lessons together. & & & & & \\
\hline 7 & You like writing summary cards after every lesson. & & & & & \\
\hline 8 & You are going to apply summary cards for other subjects. & & & & & \\
\hline
\end{tabular}

